\title{
Theoretical studies on the structural, electronic and optical properties of BeZnO alloys
}

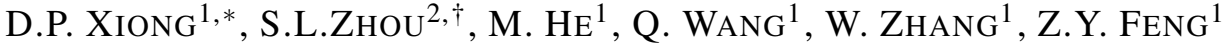 \\ ${ }^{1}$ School of Physics and Optoelectronic Engineering, Guangdong University of Technology, Guangzhou, 510006, China \\ ${ }^{2}$ College of Information Engineering, Zhejiang University of Technology, Hangzhou 310023, China
}

The structural, electronic and optical properties of $\mathrm{Be}_{\mathrm{x}} \mathrm{Zn}_{1-\mathrm{x}} \mathrm{O}$ alloys were studied using the density functional theory and Hubbard- $\mathrm{U}$ method. $\mathrm{U}_{\mathrm{o}, \mathrm{p}}=10.2 \mathrm{eV}$ for $\mathrm{O} 2 \mathrm{p}$ and $\mathrm{U}_{\mathrm{Zn}, \mathrm{d}}=1.4 \mathrm{eV}$ for $\mathrm{Zn} 3 \mathrm{~d}$ were adopted as the Hubbard $\mathrm{U}$ values. For $\mathrm{Be}_{\mathrm{x}} \mathrm{Zn}_{1-\mathrm{x}} \mathrm{O}$ alloys, the lattice constants a and $\mathrm{c}$ decrease linearly as Be concentration increases, the bandgap increases with a large bowing parameter of $6.95 \mathrm{eV}$, the formation enthalpies have the maximum value with Be concentration at 0.625 , corresponding to the possible Be concentration to form phase separation. These calculations comply well with the experimental and other theoretical results. Furthermore, optical properties, such as dielectric function $\epsilon(\omega)$, reflectivity $R(\omega)$, absorption coefficient $\alpha(\omega)$, were calculated and discussed for $\mathrm{Be}_{\mathrm{x}} \mathrm{Zn}_{1-\mathrm{x}} \mathrm{O}$ alloys with the incident photon energy ranging from $0 \mathrm{eV}$ to $30 \mathrm{eV}$.

Keywords: BeZnO alloys; DFT $+U$; electronic property

\section{Introduction}

$\mathrm{ZnO}$, as a wide direct bandgap semiconductor, has been widely used in optoelectronic devices, such as light emitting diodes (LEDs) [1, 2] and solar cells [3, 4]; especially, $\mathrm{ZnO}$ has promising applications in ultraviolet (UV) optoelectronic devices [5-7]. To produce highly efficient $\mathrm{ZnO}$-based optoelectronic devices, it is necessary to develop $\mathrm{ZnO}$-based heterostructure or quantum well $[8,9]$. To make such structures, a common method is to develop $\mathrm{ZnO}$-based alloys with the band gap smaller or larger than that of $\mathrm{ZnO}[10$ 14]. Presently, much emphasis has been focused on incorporating $\mathrm{Mg}$ or $\mathrm{Cd}$ into $\mathrm{ZnO}$ to form $\mathrm{MgZnO}$ or $\mathrm{CdZnO}$ alloys $[15,16]$. However, with increasing $\mathrm{Mg}$ or $\mathrm{Cd}$ concentration, the phase segregation may occur for $\mathrm{MgZnO}$ or $\mathrm{CdZnO}$ alloys due to the large lattice mismatch between $\mathrm{ZnO}$ and $\mathrm{MgO}$ or $\mathrm{CdO}$ [17]. Recently, $\mathrm{Be}_{\mathrm{x}} \mathrm{Zn}_{1-\mathrm{x}} \mathrm{O}$ films have been prepared on $\mathrm{Al}_{2} \mathrm{O}_{3}$ substrates using hybrid beam deposition (HBD) with $\mathrm{Be}$

\footnotetext{
*E-mail: depingxiong@gdut.edu.cn

${ }^{\dagger}$ E-mail: zhoushl@zjut.edu.cn
}

concentration varying from 0 to 1 without phase separation [18], $\mathrm{Be}_{\mathrm{x}} \mathrm{Zn}_{1-\mathrm{x}} \mathrm{O} / \mathrm{ZnO}$ was even used as an active layer to fabricate UV-LEDs [19]. It indicates that $\mathrm{Be}_{\mathrm{x}} \mathrm{Zn}_{1-\mathrm{x}} \mathrm{O}$ is another excellent candidate as $\mathrm{ZnO}$-based alloys. Presently, the knowledge on the properties of $\mathrm{Be}_{\mathrm{x}} \mathrm{Zn}_{1-\mathrm{x}} \mathrm{O}$ alloys is still limited and even contradictory, for example, Chen et al. reported $\mathrm{Be}_{\mathrm{x}} \mathrm{Zn}_{1-\mathrm{x}} \mathrm{O}$ alloys were hard to acquire with intermediate $\mathrm{Be}$ concentration $(\sim 0.6)$ [20]. Therefore, it is necessary to investigate the basic physical properties of $\mathrm{Be}_{\mathrm{x}} \mathrm{Zn}_{1-\mathrm{x}} \mathrm{O}$ alloys comprehensively.

In this paper, we present the theoretical calculations on the structural, electronic and optical properties of wurtzite $\mathrm{Be}_{\mathrm{x}} \mathrm{Zn}_{1-\mathrm{x}} \mathrm{O}$ alloys with $\mathrm{Be}$ concentration ranging from 0 to 1 . The calculations were based on the density functional theory (DFT). However, standard DFT method, due to its limitations, severely underestimates the bandgap [21]. Ding et al. [22] investigated the electronic structure of $\mathrm{Be}_{\mathrm{x}} \mathrm{Zn}_{1-\mathrm{x}} \mathrm{O}$ alloys based on DFT. The calculated bandgaps of $\mathrm{ZnO}$ and $\mathrm{BeO}$ were found to be only $0.971 \mathrm{eV}$ and $7.320 \mathrm{eV}$, respectively, which are much smaller than the experimental values of $3.37 \mathrm{eV}$ and $10.6 \mathrm{eV}$. The DFT + U method 
attempts to amend the limitation by using an orbital dependent term added to the DFT potential. The impact of $\mathrm{U}$ parameter on the properties of $\mathrm{ZnO}$ has been studied by many researches [23, 24]. In this work, to ensure the reliability of calculated results, the dependence of calculated bandgaps on the $\mathrm{U}$ values was investigated, and the $\mathrm{U}$ parameters were optimized by comparing with the experimental bandgaps of $\mathrm{ZnO}$ and $\mathrm{BeO}$.

\section{Methods and model}

The calculations were performed with the CASTEP code based on DFT [25], in which electron-ion interactions were modeled by ultrasoft pseudopotentials. The generalized gradient approximation (GGA) was used to describe the exchangecorrelation energy between electrons. The valence atomic configurations were $3 \mathrm{~d}^{10} 4 \mathrm{~s}^{2}$ for $\mathrm{Zn}, 2 \mathrm{~s}^{2} 2 \mathrm{p}^{4}$ for $\mathrm{O}$, and $2 \mathrm{~s}^{2}$ for $\mathrm{Be}$, respectively. The wave functions of the valence electrons were expanded by a plane-wave basis set with the cutoff energy fixed at $380 \mathrm{eV}$. K-point grid sampling in the supercells was set at $4 \times 4 \times 2$. The convergence threshold was set at $10^{-6} \mathrm{eV}$ for self-consistent iterations. In the optimization process, the changes in energy were set at $10^{-5} \mathrm{eV} /$ atom, maximum force and maximum stress were set at $0.03 \mathrm{eV} / \AA$ and $0.05 \mathrm{GPa}$, and maximum displacement tolerance was set at $0.001 \AA$.

$\mathrm{ZnO}$ and $\mathrm{BeO}$ have the same wurtzite structure in the normal conditions, therefore, the $\mathrm{Be}_{\mathrm{x}} \mathrm{Zn}_{1-\mathrm{x}} \mathrm{O}$ alloys are of wurtzite structure in the entire range. To simulate wurtzite $\mathrm{Be}_{\mathrm{x}} \mathrm{Zn}_{1-\mathrm{x}} \mathrm{O}$ alloys with various $\mathrm{Be}$ concentrations, we constructed 32-atom $\mathrm{Be}_{\mathrm{n}} \mathrm{Zn}_{16-\mathrm{n}} \mathrm{O}_{16}$ supercell as shown in Fig. 1, which corresponds to $2 \times 2 \times 2$ primitive unit cells. The Be doping level is 0, 0.0625, 0.125 with $\mathrm{n}=0,1,2$, and so on. At the same Be concentration, different configurations of $\mathrm{Be}_{\mathrm{n}} \mathrm{Zn}_{16-\mathrm{n}} \mathrm{O}_{16}$ supercell do not make big differences in the calculations [26, 27]. Therefore, we have taken one special configuration for each Be-doped concentration case with the $\mathrm{Be}$ atoms distributed in the wurtzite $\mathrm{Be}_{\mathrm{n}} \mathrm{Zn}_{16-\mathrm{n}} \mathrm{O}_{16}$ supercell homogeneously, namely, the distances between the Be atoms were assumed as large as possible.

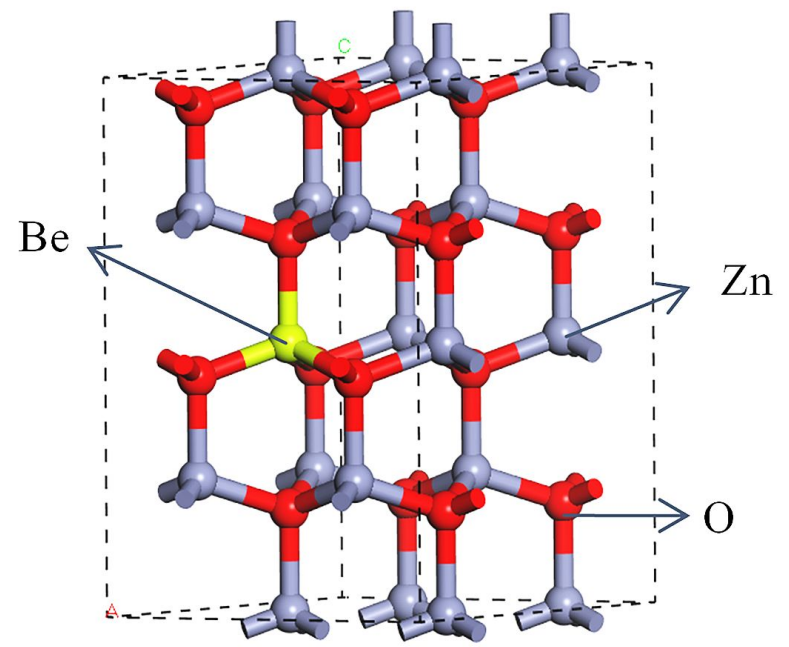

Fig. 1. 32-atom $\mathrm{Be}_{1} \mathrm{Zn}_{15} \mathrm{O}_{16}$ supercell. Gray, red and green spheres represent $\mathrm{Zn}, \mathrm{O}$ and $\mathrm{Be}$ atoms, respectively.

\section{Results and discussion}

\subsection{Structural properties}

To provide the properties of $\mathrm{BeZnO}$ alloys more accurately, we adopted DFT $+\mathrm{U}_{\mathrm{p}}+\mathrm{U}_{\mathrm{d}}$ method in this work, $U$ value is an important parameter and includes both $\mathrm{p}$ states and $\mathrm{d}$ states [28]. By setting $\mathrm{U}_{\mathrm{Zn}, \mathrm{d}}=10.5 \mathrm{eV}$ and $\mathrm{U}_{\mathrm{O}, \mathrm{p}}=7.0 \mathrm{eV}$, Sheetz et al. [29] calculated the band-gap of $\mathrm{ZnO}$ and the value of $3.30 \mathrm{eV}$ was obtained, which is wellconsistent with the experimental value of $3.37 \mathrm{eV}$. However, by setting $\mathrm{U}_{\mathrm{O}, \mathrm{p}}=7.0 \mathrm{eV}$, the calculated band-gap of $\mathrm{BeO}$ is only $9.47 \mathrm{eV}$, which is still much smaller than the experimental value of $10.6 \mathrm{eV}$ [30]. Therefore, it was necessary to reoptimize both $\mathrm{U}_{\mathrm{d}}$ for $\mathrm{Zn} 3 \mathrm{~d}$ and $\mathrm{U}_{\mathrm{p}}$ for $\mathrm{O} 2 \mathrm{p}$. Fig. 2 shows the relationship between the bandgaps of wurtzite $\mathrm{BeO}$ and $\mathrm{ZnO}$ and the value of $\mathrm{U}$. When $\mathrm{U}_{\mathrm{O}, \mathrm{p}}=10.2 \mathrm{eV}$, the calculated bandgap of $\mathrm{BeO}$ is $10.58 \mathrm{eV}$, which is close to the experimental value of $10.6 \mathrm{eV}$, as shown in Fig. 2a. Therefore, we fixed $\mathrm{U}_{\mathrm{O}, \mathrm{p}}=10.2 \mathrm{eV}$ and changed $\mathrm{U}_{\mathrm{Zn}, \mathrm{d}}$ from $1.1 \mathrm{eV}$ to $1.6 \mathrm{eV}$ as shown in Fig. 2b. When $\mathrm{U}_{\mathrm{Zn}, \mathrm{d}}=1.4 \mathrm{eV}$, the calculated bandgap of $\mathrm{ZnO}$ is $3.369 \mathrm{eV}$, which agrees well with the experimental value of $3.37 \mathrm{eV}$. Therefore, $\mathrm{U}_{\mathrm{O}, \mathrm{p}}=10.2 \mathrm{eV}$ and $\mathrm{U}_{\mathrm{Zn}, \mathrm{d}}=1.4 \mathrm{eV}$ were adopted as the $\mathrm{U}$ values in this study. 

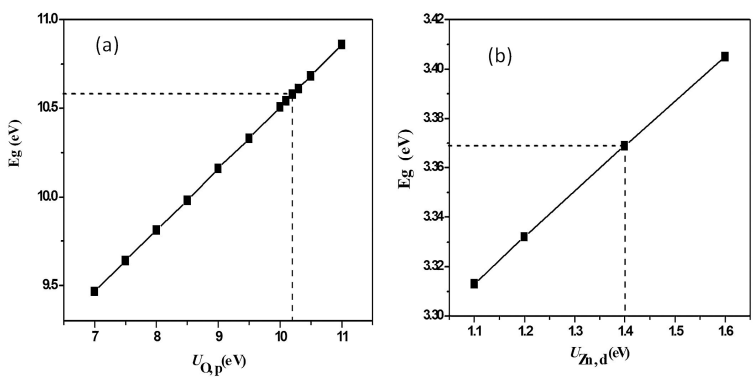

Fig. 2. The relationship between the value of $U$ and the bandgap of $\mathrm{BeO}$ and $\mathrm{ZnO}$ : (a) the band-gap of $\mathrm{BeO}$ depending on $\mathrm{U}_{\mathrm{O}, \mathrm{p}}$; (b) the bandgap of $\mathrm{ZnO}$ depending on $\mathrm{U}_{\mathrm{Zn}, \mathrm{d}}$.
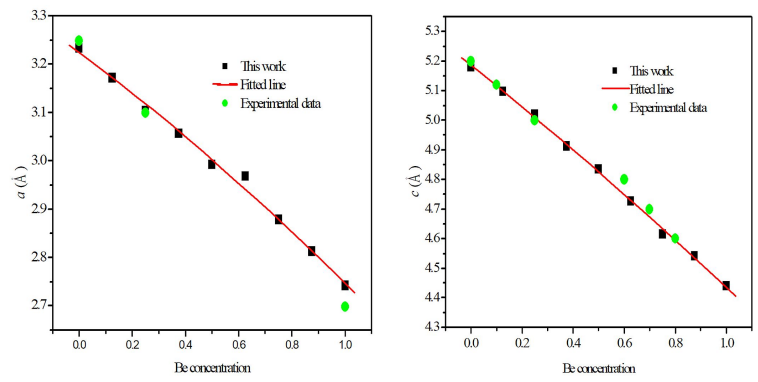

Fig. 3. The calculated lattice constants a and $\mathrm{c}$ of $\mathrm{Be}_{\mathrm{x}} \mathrm{Zn}_{1-\mathrm{x}} \mathrm{O}$ alloys as a function of Be concentration, compared with the available experimental data $[31,32]$.

By optimizing $\mathrm{Be}_{\mathrm{n}} \mathrm{Zn}_{16-\mathrm{n}} \mathrm{O}_{16}$ supercells, we firstly obtained the lattice constants and total energies for $\mathrm{Be}_{\mathrm{x}} \mathrm{Zn}_{1-\mathrm{x}} \mathrm{O}_{16}$ with different $\mathrm{Be}$ concentrations; the lattice constant a was ultimately determined by averaging two slightly different a values of the unit cell. Fig. 3 shows the calculated lattice constants of $\mathrm{Be}_{\mathrm{x}} \mathrm{Zn}_{1-\mathrm{x}} \mathrm{O}$ alloys as a function of $\mathrm{Be}$ concentration, compared with the available experimental data [31, 32]. In particular, for $\mathrm{ZnO}$ the calculated constants are $\mathrm{a}=3.233 \AA$ and $\mathrm{c}=5.181 \AA$, for $\mathrm{BeO} \mathrm{a}=2.739 \AA$ and $\mathrm{c}=4.434 \AA$, which is also in good agreement with the experimental data for $\mathrm{ZnO}(\mathrm{a}=3.249 \AA$ and $\mathrm{c}=5.206 \AA)$ and $\mathrm{BeO}(\mathrm{a}$ $=2.698 \AA$ and $\mathrm{c}=4.409 \AA)$, indicating the reliability of these calculations. In addition, it can been seen from Fig. 3 that the lattice constants a and $\mathrm{c}$ have a linear relationship with Be concentration $\mathrm{x}$, i.e. they comply well with a simple Vegard law, which is consistent with the other theoretical work by Ding et al. [22] and Fan et al. [33]. Obviously, doping of Be results in a linear decrease of the lattice constants, which is due to the fact that the ionic radius of $\mathrm{Be}^{2+}$ is much smaller than that of $\mathrm{Zn}^{2+}$.

\subsection{Electronic properties}

The band structures of $\mathrm{Be}_{\mathrm{n}} \mathrm{Zn}_{16-\mathrm{n}} \mathrm{O}$ supercells were calculated along high symmetry points. They all indicate direct band-gap structure. Fig. 4 shows the bandgaps of $\mathrm{Be}_{\mathrm{x}} \mathrm{Zn}_{1-\mathrm{x}} \mathrm{O}$ as a function of $\mathrm{Be}$ concentration, compared with the experimental data $[30,32]$. It can be seen that the theoretical data comply well with the experimental results. For ternary alloys, the bandgap generally can be defined as follows:

$$
E_{g}(x)=x \cdot E_{g}(\mathrm{BeO})+(1-x) \cdot E_{g}(\mathrm{ZnO})-b \cdot x \cdot(1-x)
$$

where $\mathrm{b}$ is the bowing parameter, $\mathrm{E}_{\mathrm{g}}(\mathrm{BeO})$ and $\mathrm{E}_{\mathrm{g}}(\mathrm{ZnO})$ are the bandgaps of $\mathrm{BeO}$ and $\mathrm{ZnO}$, respectively. We fitted the calculated bandgaps by quadratic equation, and a large bowing parameter of about $6.95 \mathrm{eV}$ was obtained, which is very close to the experimental value of $6.32 \mathrm{eV}$ by $\mathrm{Yu}$ et al. [34], and also is not far from the theoretical value of $5.6 \mathrm{eV}$ by Ding et al. [22].

As we know, the band structure near Fermi level usually plays a key role for the electronic and optical properties of semiconductor materials. Therefore, the conduction band minimum (CBM) and valence band maximum (VBM) of $\mathrm{Be}_{\mathrm{x}} \mathrm{Zn}_{1-\mathrm{x}} \mathrm{O}$ with various $\mathrm{Be}$ concentrations were plotted together for further analysis, to facilitate the comparison. All energies at the G-point were shifted to zero as shown in Fig. 5. It can be seen from Fig. 5a and Fig. 5b that the CBMs gradually flats out with $\mathrm{Be}$ concentration increasing from 0 to 1, i.e. the curvature of the CBMs gets smaller. In solid-state physics, the effective mass is inversely proportional to the curvature. Smaller curvature indicates larger effective mass and lower carrier mobility for electrons in conduction bands. While the curvature of VBMs gets smaller with Be concentration increasing from 0 to 0.5 (Fig. $5 \mathrm{a}$ ), then it gets larger with Be concentration increasing from 0.5 to 1 (Fig. 5(b)), indicating that the effective mass of 


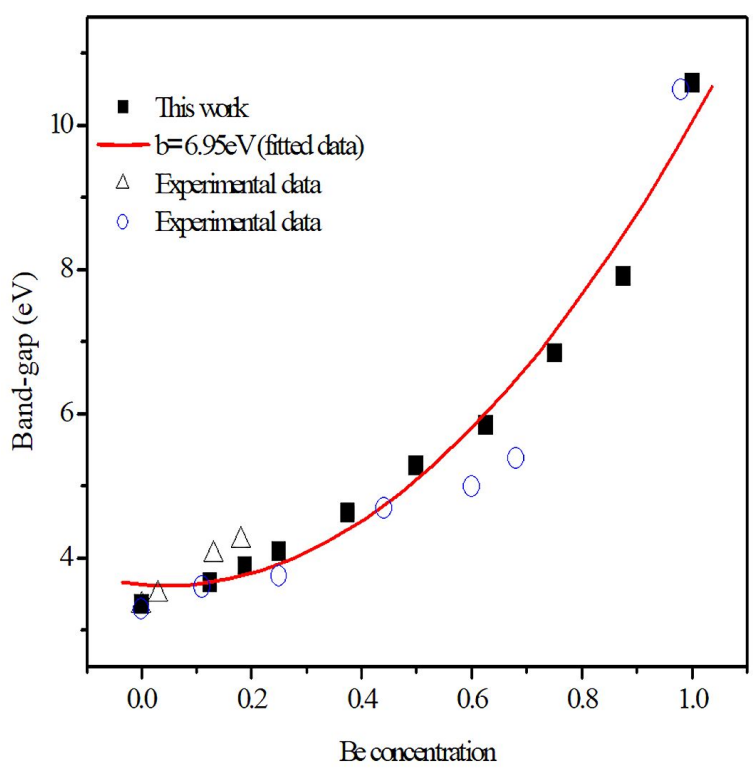

Fig. 4. The calculated band-gaps of $\mathrm{Be}_{\mathrm{x}} \mathrm{Zn}_{1-\mathrm{x}} \mathrm{O}$ alloys versus $\mathrm{Be}$ concentration $\mathrm{x}$, compared with the experimental results. The data shown by hollow circles and hollow diamonds come from [30] and [32], respectively.

holes in valence band first increases and then decreases with Be concentration varied from 0 to 1 .

To examine the relative stability of $\mathrm{Be}_{\mathrm{x}} \mathrm{Zn}_{1-\mathrm{x}} \mathrm{O}$ alloys, the formation enthalpies of mixing were calculated by taking the difference in total energy between the $\mathrm{Be}_{\mathrm{x}} \mathrm{Zn}_{1-\mathrm{x}} \mathrm{O}$ alloys and the weighted sum of $\mathrm{BeO}$ and $\mathrm{ZnO}$ [35]:

$$
\begin{aligned}
& \Delta H(x)=E_{t o t}\left(\mathrm{Be}_{x} \mathrm{Zn}_{1-x} \mathrm{O}\right)-\left[x \cdot E_{t o t}(\mathrm{BeO})\right. \\
& \left.+(1-x) \cdot E_{t o t}(\mathrm{ZnO})\right]
\end{aligned}
$$

where $\mathrm{E}_{\text {tot }}\left(\mathrm{Be}_{\mathrm{x}} \mathrm{Zn}_{1-\mathrm{x}} \mathrm{O}\right), \mathrm{E}_{\text {tot }}(\mathrm{BeO})$ and $\mathrm{E}_{\text {tot }}(\mathrm{ZnO})$ are the total energies of $\mathrm{Be}_{\mathrm{x}} \mathrm{Zn}_{1-\mathrm{x}} \mathrm{O}, \mathrm{BeO}$ and $\mathrm{ZnO}$ supercells. Fig. 6 shows the calculated formation enthalpies of $\mathrm{Be}_{\mathrm{x}} \mathrm{Zn}_{1-\mathrm{x}} \mathrm{O}$ alloys at various Be concentrations. It can be seen that the formation enthalpies are positive in the whole range, and they increase to the maximum value with $\mathrm{Be}$ concentration $\mathrm{x}=0.625$. Higher formation enthalpies imply that it is more difficult to form stable crystals, therefore, for $\mathrm{Be}_{\mathrm{x}} \mathrm{Zn}_{1-\mathrm{x}} \mathrm{O}$ alloys the most possible $\mathrm{Be}$ concentration $\mathrm{x}$ to form phase separation is 0.625 compared to the other $\mathrm{x}$ values.
Li et al. [36] calculated formation enthalpies of $\mathrm{Be}_{\mathrm{x}} \mathrm{Zn}_{1-\mathrm{x}} \mathrm{O}$ at $\mathrm{T}=0 \mathrm{~K}$ and revealed that they reached the maximum value at $\mathrm{x} \sim 0.55$. Chen et al. [20] grew $\mathrm{Be}_{\mathrm{x}} \mathrm{Zn}_{1-\mathrm{x}} \mathrm{O}$ alloys by plasma-assisted molecular beam epitaxy. When Be concentration $\mathrm{x}=0.62, \mathrm{Be}_{\mathrm{x}} \mathrm{Zn}_{1-\mathrm{x}} \mathrm{O}$ alloys tended to form a noncrystalline structure.

\subsection{Optical properties}

The optical properties of a material can be described by dielectric function $\epsilon(\omega)=\epsilon_{1}(\omega)+$ $i \epsilon_{2}(\omega)$. In this function $\epsilon_{1}(\omega)$ and $\epsilon_{2}(\omega)$ are the real and imaginary part. They can be calculated according to the Kramers-Kronig dispersion relation [37, 38]. In this way, other optical properties, such as absorption coefficient $\alpha(\omega)$, reflectivity $\mathrm{R}(\omega)$ can also be acquired. The related formulas are listed below:

$$
\varepsilon_{2}(\omega)=\frac{2 e^{2} \pi}{\Omega \varepsilon_{0}} \sum_{k, c, v}\left|\left\langle\varphi_{c}^{k}|u \cdot r| \varphi_{v}^{k}\right\rangle\right|^{2} \delta\left(E_{c}^{k}-E_{v}^{k}-\omega\right)
$$

$$
\begin{gathered}
\varepsilon_{1}(\omega)=1+\frac{2}{\pi} \rho_{0} \int_{0}^{\mathrm{inf}} \frac{\omega^{\prime} \varepsilon_{2}(\omega)}{\omega^{\prime 2}-\omega^{2}} d \omega^{\prime} \\
\alpha(\omega)=\sqrt{2}\left[\sqrt{\varepsilon_{1}^{2}(\omega)+\varepsilon_{2}^{2}(\omega)}-\varepsilon_{1}(\omega)\right]^{1 / 2} \\
R(\omega)=\left|\frac{\sqrt{\varepsilon(\omega)}-1}{\sqrt{\varepsilon(\omega)}+1}\right|^{2}
\end{gathered}
$$

where $\Omega$ is the volume of unit cell, e is the electronic charge, $\mathrm{u}$ is the vector of electric field defining the polarization, $\omega$ is the frequency of incident light; and $\varphi_{\mathrm{c}}^{\mathrm{k}}$ and $\varphi_{\mathrm{v}}^{k}$ are the wave functions of valence and conduction band, $\mathrm{E}_{\mathrm{c}}^{\mathrm{k}}$ and $\mathrm{E}_{\mathrm{v}}^{\mathrm{k}}$ are the intrinsic energy, respectively.

Fig. 7 shows the calculated imaginary part $\epsilon_{2}(\omega)$ and real part $\epsilon_{1}(\omega)$ of dielectric function as a function of photon energy for $\mathrm{Be}_{\mathrm{x}} \mathrm{Zn}_{1-\mathrm{x}} \mathrm{O}$ alloys. In Fig. 7a, it can be seen that the shapes of $\epsilon_{2}(\omega)$ spectra for all concentrations of $\mathrm{Be}_{\mathrm{x}} \mathrm{Zn}_{1-\mathrm{x}} \mathrm{O}$ are similar except some differences in details. For pure $\mathrm{ZnO}$, five obvious peaks exist; in case of 

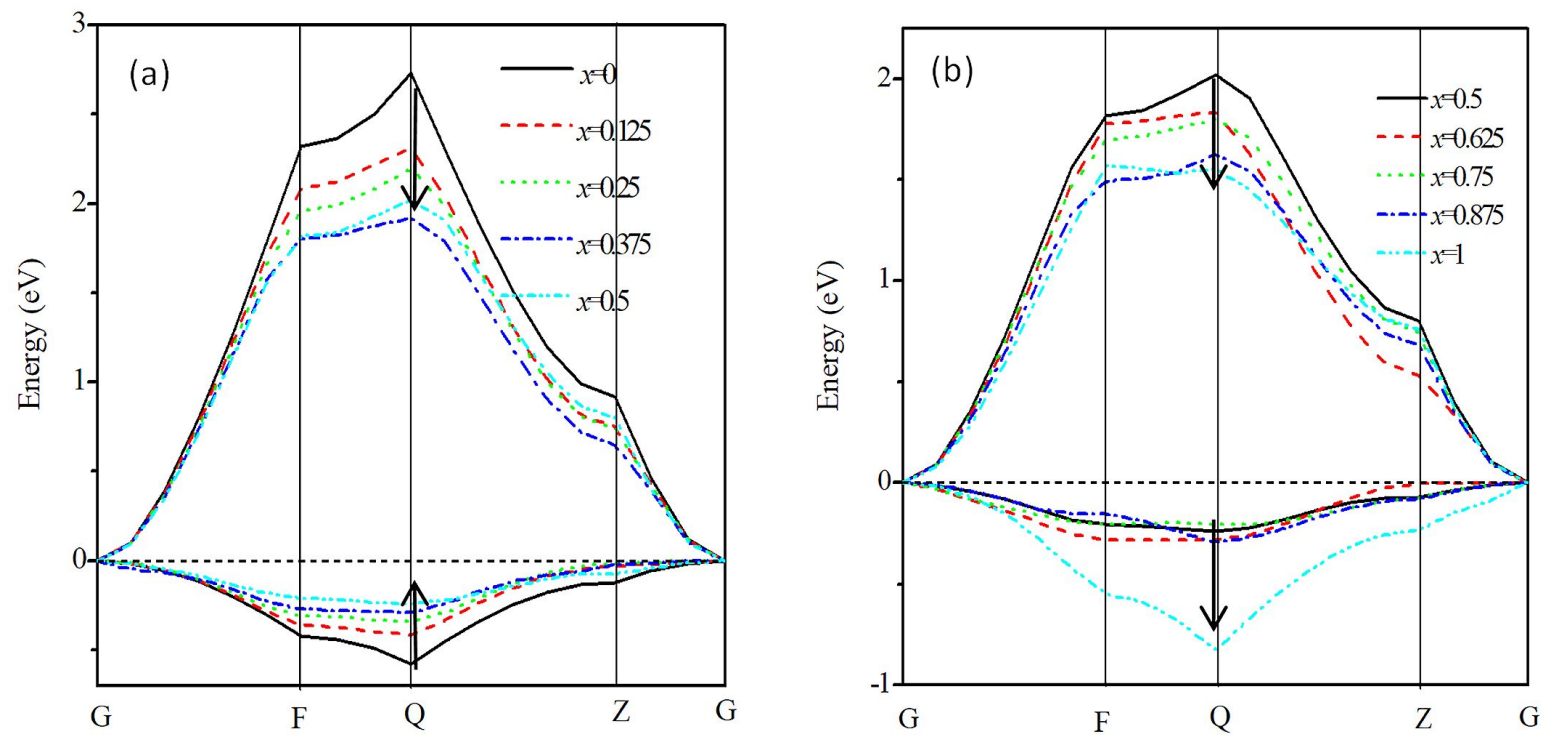

Fig. 5. The CBMs and VBMs of $\mathrm{Be}_{\mathrm{x}} \mathrm{Zn}_{1-\mathrm{x}} \mathrm{O}$ with various Be concentrations $\mathrm{x}$, (a) $0 \leqslant \mathrm{x} \leqslant 0.5$, (b) $0.5 \leqslant \mathrm{x} \leqslant$ 1. The dash line at zero is the Fermi level, the arrows indicate the variation of VBMs and CBMs with the increase of Be concentration.

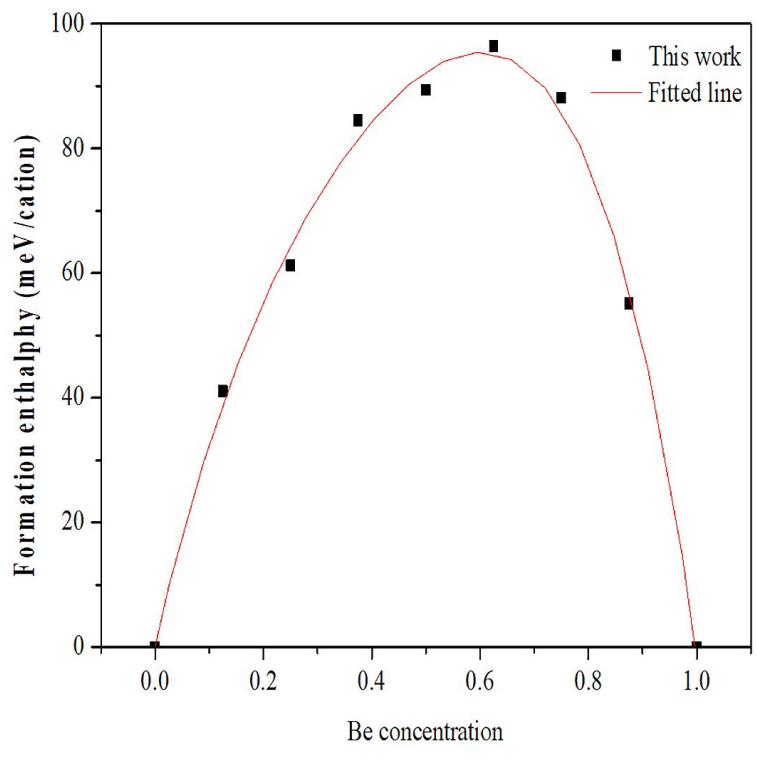

Fig. 6. The calculated formation enthalpies of $\mathrm{Be}_{\mathrm{x}} \mathrm{Zn}_{1-\mathrm{x}} \mathrm{O}$ alloys at various Be concentrations, at $\mathrm{x}=0.625$, they achieve the maximum value.

$\mathrm{Be}_{\mathrm{x}} \mathrm{Zn}_{1-\mathrm{x}} \mathrm{O}$ alloys with $\mathrm{Be}$ doping, the two small peaks in lower energy gradually combine to form one peak with Be concentration increasing. Similar situation is for the two middle large peaks. In addition, in Fig. 7a the energy positions of all the peaks gradually shift to high energy region with increasing Be concentration. As we know, these peaks correspond to the transitions between various energy levels, the first peak corresponds to the transition between the VBM and CBM. The energy shifts can be connected with the bandgap increase as shown in Fig. 4. In Fig. 7b, we present our calculated real part $\epsilon_{1}(\omega)$ of the dielectric function. The zero frequency value $\epsilon_{1}(0)$ is the static dielectric constant; it is related to the refractive index and depends on the bandgap as $\epsilon_{1}(0) \approx 1+\left(\hbar \omega_{\mathrm{p}} / \mathrm{E}_{\mathrm{g}}\right)^{2}$, where $\omega_{p}$ is the plasma frequency. It can be seen in Fig. $7 b$ that the static dielectric constant $\epsilon_{1}(0)$ of pure $\mathrm{ZnO}$ is about 1.5 . It gradually decreases with increasing Be concentration, which is consistent with the fact that the bandgaps of $\mathrm{Be}_{\mathrm{x}} \mathrm{Zn}_{1-\mathrm{x}} \mathrm{O}$ alloys become larger as shown in Fig. 4. The decrease of the static dielectric constant with the bandgap increase has also been confirmed by Yu et al. [39]. In addition, a steep decrease of $\epsilon_{1}(\omega)$ is observed from $8.0 \mathrm{eV}$ to $13 \mathrm{eV}$ for $\mathrm{Be}_{\mathrm{x}} \mathrm{Zn}_{1-\mathrm{x}} \mathrm{O}$ with various $\mathrm{Be}$ concentrations; it even falls to negative values when Be concentration is larger than 0.875 , and the minimum $\epsilon_{1}(\omega)$ shifts to larger energy as $x$ is increasing. It can also be seen from Fig. 7b that in the energy region larger than $18 \mathrm{eV}$ for $\mathrm{ZnO}$ and $22 \mathrm{eV}$ for 

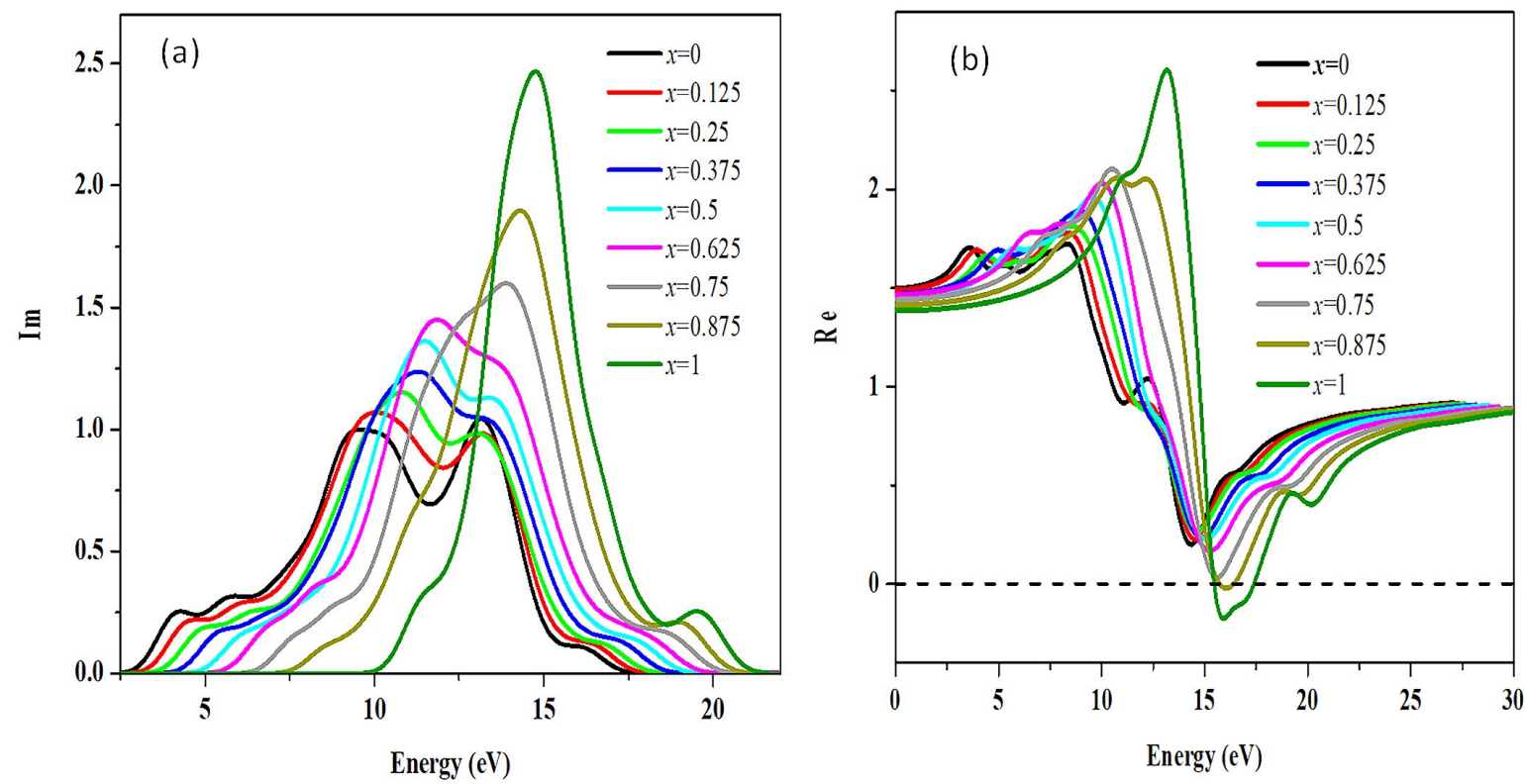

Fig. 7. The calculated dielectric function of $\mathrm{Be}_{\mathrm{x}} \mathrm{Zn}_{1-\mathrm{x}} \mathrm{O}$ alloys with different Be concentrations $\mathrm{x}$ as a function of photon energy, (a) the imaginary part $\epsilon_{2}(\omega)$, (b) the real part $\epsilon_{1}(\omega)$.

$\mathrm{BeO}$, the $\epsilon_{1}(\omega)$ spectra are flat and have no peaks, which is due to the fact that the frequency of the incident photons is much larger than the resonance frequency of the electron in the material. Therefore, the electrons cannot feel the incident electromagnetic radiation and behave as free electrons.

In Fig. 8 we have plotted the reflectivity and absorption spectra of $\mathrm{Be}_{\mathrm{x}} \mathrm{Zn}_{1-\mathrm{x}} \mathrm{O}$ alloys with different $\mathrm{Be}$ concentrations. The normal incidence reflectivity can provide information on transitions between various energy levels. It can be seen in Fig. 8a, for pure $\mathrm{ZnO}$ that $\mathrm{R}_{1}(\omega)$ has several maxima at $3.7 \mathrm{eV}, 8.0 \mathrm{eV}$ and $14.4 \mathrm{eV}$, then it finally starts falling to zero, while for $\mathrm{BeO}$ this behavior is observed above $20.1 \mathrm{eV}$. Moreover, the reflectivity structure shifts to larger energy and in the range of $0 \mathrm{eV}$ to $3.5 \mathrm{eV}$, the reflectivity decreases with increasing Be concentration. Similar characteristics have also been obtained by Lei et al. [40]. In Fig. 8b the absorption spectra show that $\mathrm{ZnO}$ has absorption region ranging from $2.6 \mathrm{eV}$ to $18.0 \mathrm{eV}$, while for $\mathrm{BeO}$, the absorption region starts from $10.0 \mathrm{eV}$ and ends at $22.0 \mathrm{eV}$. In these regions they all have one strong and several small absorption peaks, and these features are also shown in the ternary $\mathrm{Be}_{\mathrm{x}} \mathrm{Zn}_{1-\mathrm{x}} \mathrm{O}$ alloys. It can be observed that the absorption edge shifts toward high energy region with Be concentration increasing, which is consistent with the experimental results by $\mathrm{Su}$ et al. [41] and can be explained by the bandgap increase. Similarly, with Be concentration increasing, the absorption coefficient decreases in the energy range of $0 \mathrm{eV}$ to $10 \mathrm{eV}$, similar to the behavior of the reflectivity in Fig. 8a. In the energy range of $0 \mathrm{eV}$ to $3.5 \mathrm{eV}$, the transmittance of $\mathrm{Be}_{\mathrm{x}} \mathrm{Zn}_{1-\mathrm{x}} \mathrm{O}$ decreases with increasing Be concentration, which was also demonstrated by the experimental results by $\mathrm{Su}$ et al. [41]. In the whole, the shapes of the curves, the positions of the peaks, and the changes with Be concentration increase are similar to those of the imaginary dielectric spectra in Fig. 7a.

\section{Conclusion}

In this study, we have constructed 32-atom $\mathrm{Be}_{\mathrm{n}} \mathrm{Zn}_{16-\mathrm{n}} \mathrm{O}_{16}$ supercells and adopted DFT $+\mathrm{U}$ method to investigate the structural and electronic properties of $\mathrm{Be}_{\mathrm{x}} \mathrm{Zn}_{1-\mathrm{x}} \mathrm{O}$ alloys. $\mathrm{U}_{\mathrm{o}, \mathrm{p}}=10.2 \mathrm{eV}$ for $\mathrm{O} 2 \mathrm{p}$ and $\mathrm{U}_{\mathrm{Zn}, \mathrm{d}}=1.4 \mathrm{eV}$ for $\mathrm{Zn} 3 \mathrm{~d}$ were optimized as the Hubbard $U$ values. Using these $U$ values, the calculated bandgaps of $\mathrm{ZnO}$ and $\mathrm{BeO}$ are $3.37 \mathrm{eV}$ and $10.58 \mathrm{eV}$, respectively, which is 

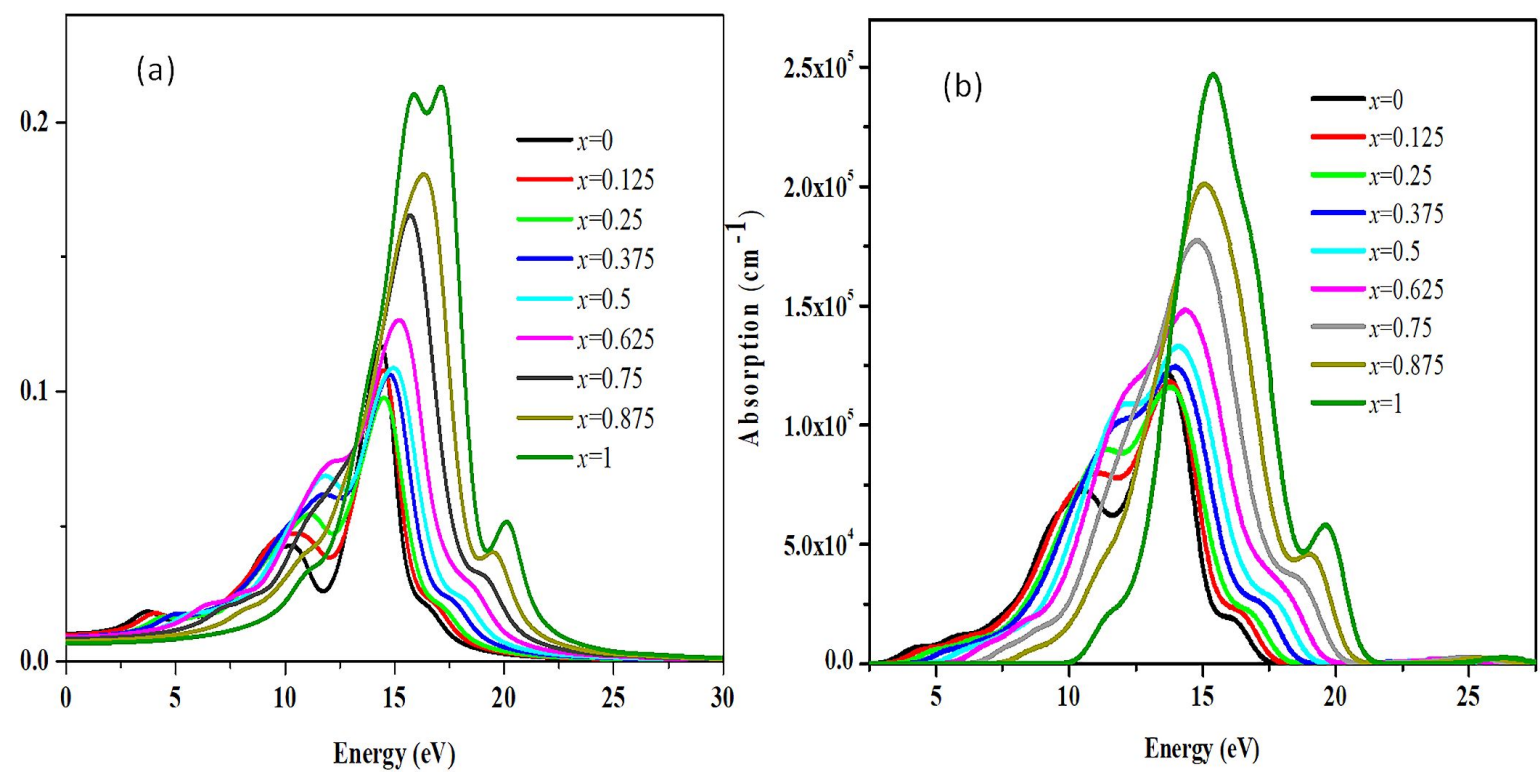

Fig. 8. (a) Reflectivity, and (b) absorption spectra of $\mathrm{Be}_{\mathrm{x}} \mathrm{Zn}_{1-\mathrm{x}} \mathrm{O}$ alloys with different $\mathrm{Be}$ concentrations as a function of photon energy.

equal to the experimental data. For $\mathrm{Be}_{\mathrm{x}} \mathrm{Zn}_{1-\mathrm{x}} \mathrm{O}$ alloys. The lattice constants a and c decrease linearly and comply well with a simple Vegard law with increasing Be concentration. The band structures for $\mathrm{Be}_{\mathrm{x}} \mathrm{Zn}_{1-\mathrm{x}} \mathrm{O}$ with different Be concentrations were calculated. All the compounds indicate direct bandgap structure and the bandgap values increase with a large bowing parameter of $6.95 \mathrm{eV}$. The CBMs and VBMs were plotted together and their curvatures were compared. In addition, to examine the relative stability of $\mathrm{Be}_{\mathrm{x}} \mathrm{Zn}_{1-\mathrm{x}} \mathrm{O}$ alloys, the formation enthalpies of mixing were calculated and showed the maximum value at Be concentration of 0.625. Furthermore, optical properties such as dielectric function $\epsilon(\omega)$, reflectivity $R(\omega)$, absorption coefficient $\alpha(\omega)$ were calculated and discussed for $\mathrm{Be}_{\mathrm{x}} \mathrm{Zn}_{1-\mathrm{x}} \mathrm{O}$ alloys with the incident photon energy ranging from $0 \mathrm{eV}$ to $30 \mathrm{eV}$. Our calculated results revealed that the structural, electronic and optical properties of $\mathrm{Be}_{\mathrm{x}} \mathrm{Zn}_{1-\mathrm{x}} \mathrm{O}$ alloys, including lattice constants, bandgaps, absorption coefficient, can be large-scale tuned through Be concentration. These characteristics indicate that $\mathrm{Be}_{\mathrm{x}} \mathrm{Zn}_{1-\mathrm{x}} \mathrm{O}$ may be an excellent candidate for application in UV optoelectronic devices, like other ZnO-based alloys.

\section{Acknowledgements}

This work was supported by the Science and Technology Planning Project of Guangzhou city (2016201604030035 and 201604016095), the Science and Technology Planning Project of Guangdong Province (2015B010112002), the Science and Technology Planning Project of Zhongshan city (2017A1008). We also acknowledge the R\&D Center for Semiconductor Lighting of Chinese Academy of Sciences providing us the use of CASTEP simulation program.

\section{References}

[1] Lei P.H., Ding M.J., LeE Y.C., Chung M.J., J. Alloy. Compd., 509 (2011), 6152.

[2] Zhang Z.Z., Wei Z.P., Lu Y.M., Shen D.Z., YaO B., Li B.H.,J. Cryst. Growth, 301 (2007), 362.

[3] Zhang Q., Dandeneau C.S., Zhou X., CaO G., Adv. Mater., 21 (2009), 4087.

[4] Wu.F, Qiao QiaO. Q.Q. Bahrami B., Chen K., Pathak R., Mabrouk R., Tong Y.H., Appl. Surf. Sci., 456(2018), 124.

[5] Hwang D.K., Kang S.H., Lim J.H., Yang E.J., OH Y.J., Yang J.H., Park S.J., Appl. Phys. Lett., 86 (2005), 222101.

[6] ZhU H., Shan C.X., Li B.H., Zhang Z.Z., YAO B., SHEn D.Z., Appl. Phys. Lett., 99 (2011), 101110.

[7] Wen J., Hu Y.H., ZhU K.J., Li Y.F., SONG J.Z., Curr. Appl. Phys., 14 (2014), 359.

[8] Biavan N.L., Hungues M., Montes Bajo M., Tamayo Arriola J., Jollivet A.A., Lefebvre D., Appl. Phys. Lett., 111 (2017), 231903. 
[9] Bajo M.M., Tamayo-Arriola J., Biavan N.L., Ulloa J.M., Vennegues P., Lefebvre D., Phys. Rev. Appl., 10 (2018), 034022.

[10] QIU M.X., Zhang Y.Z., Ye Z.Z., He H.P, TANG H.P., Gu X.Q., ZhU L.P., ZhaO B.H., J. Phys. D: Appl. Phys., 40 (2007), 3229.

[11] Polyakov A.Y., Smimov N.B., Govorkov A.V., Kozhukhova E.A., Beloqorokhov A.I., Markov A.V., Kim H.S., Norton D.P., PEARTON S.J., J. Electrochem. Soc., 154 (2007), 825.

[12] Thangavel R., Rajagopalan M., Kumar J., Solid State Commun., 137 (2006), 507.

[13] Hu Y.H., CaI B, Hu Z.Y., LiU Y.L., Zhang S.L., Zeng H.B., Curr. Appl. Phys., 15 (2015), 423.

[14] Bai L.N., Zheng B.J., Lian J.S., Jiang Q., Solid State Sci., 14 (2012), 698.

[15] GOWRISHANKAR S., BALAKRISHNAN L., GOPALAKRISHNAN N., Ceram. Int., 40 (2014), 2135.

[16] Xiong D.P., Tang X.G., ZhaO W.R., LiU Q.X., WANG Y. H., ZHOU S.L., Vacuum, 89 (2013), 254.

[17] Du X.L., Mei Z.X., LiU Z.L., Guo Y., Zhang T.C., Adv. Mater., 21(2009), 4625.

[18] RyU Y.R., Lee T.S., White H.W., J. Cryst. Growth, 261 (2004), 502.

[19] RyU Y.R., LeE T.S., LubGuban J.A., White H.W., Appl. Phys. Lett., 88 (2006), 241108.

[20] Chen M., Zhu Y., Su L., Appl. Phys. Lett., 102 (2013), 202103.

[21] Godby R.W., Schluter M., Sham L.J., Phys. Rev. $B, 36$ (1987), 6497.

[22] Ding S.F., Fan G.H., Li S.T., Chen K., Xiao B., Phys. B, 394 (2007), 127.

[23] Ma X., Wu Y., Lu Y., Xu J., Wang Y., Zhu Y., J. Phys. Chem. C, 115 (2011), 16963.

[24] Ma X., Lu B., Li D., Shi R., Pan C., Zhu Y., J. Phys. Chem. C, 115 (2011), 4680.

[25] Segall M.D., Lindan P.J.D., Probert M.J., Pickard C.J., HaSniP P.J., Clark S.J., PAYNe M.C., J. Phys. Condens. Matter, 14 (2002), 2717.
[26] Xiong D.P., He M., Wang Q., Feng Z.Y., Adv. Soc. Sci.-Ed. Hum. Res., 130 (2017), 585.

[27] Bai L.N., Zheng B.J., Lian J.S., Jiang Q., Solid State Sci., 14 (2012), 698.

[28] Shao G., J. Phys. Chem. C, 113 (2009), 6800.

[29] Sheetz R.M., Ponomareva I., Richter E., AnDriotis A.N., MENON M., Phys. Rev. B, 80 (2009), 195314.

[30] Ryu Y.R., LeE T.S., Lubguban J.A., Comman A.B., White H.W., Appl. Phys. Lett., 88 (2006), 052103.

[31] PARK D.S., KRUPSKi A., SANChez A.M., Choi C.J., Yi M.S., LeE H.H., MCConville C.F., Appl. Phys. Lett., 104 (2014), 141902.

[32] Khoshman J.M., Ingram D.C., Kordesch M.E., Appl. Phys. Lett., 92 (2008), 091902.

[33] FAN X.F., ZhU Z.X., ONG Y.S., LU Y.M., SHEN Z.X., Kuo J.L., Appl. Phys. Lett., 91 (2007), 121121

[34] YU J.H., KIM J.H., YANG H.J., KIM T.S., JEONG T.S., Youn C.J., HONG K.J., J. Mater. Sci., 47 (2012), 5529.

[35] Paiva R.D., Alves J.L.A., Nogueira R.A., Mater. Sci. Eng. B, 93 (2002), 2.

[36] Li M.K., Luo M.H., ZhU J.K., Long D.B., MiaO L.S., HE Y.B., J. Appl. Phys., 121 (2017), 205101.

[37] Garcia J.C., SCOlFARO L.M.R., LiNO A.T., Freire V.N., Farias G.A., Silva C.C., Leite Alves H.W., Rodrigues S.C.P., DAsilva E.F., J. Appl. Phys., 100 (2006), 104103.

[38] Shen X.C., Science Press, Beijing, 1992, p. 24.

[39] Yu Y.H., LeE S.C., YANG C.S., Choi C.K., JunG W.K., Phys. Soc., 42 (2003), 682.

[40] Lei X., Wong C.H., Buntov E.A., Zatsepin A.F., Zhao G.J., Boukhvalov D.W., Optik, 178 (2019), 691.

[41] Su L.X., Zhu Y., Zhang Q.L., Chen M.M., Wu T.Z., Gui X.C., Appl. Surf. Sci., 274 (2013), 341.

Received 2018-09-15 Accepted 2019-04-23 